\title{
A longitudinal study of the residents’ perceptions of tourism impacts using data from the sunshine coast Australia
}

\author{
Bishnu Sharma ${ }^{\mathrm{i}}$ \\ Pam Dyer ii
}

University of the Sunshine Coast, (Australia)

\begin{abstract}
This study investigates whether there has been a change in residents' perceptions of living and tourism impacts, on the Sunshine Coast, in 2009 from their perceptions of 2008. In 2009 more respondents reported that lifestyle and general pace of life were the key attractions of living on the Sunshine Coast. The results also demonstrate a significant increase in residents' perceptions that tourism is likely to have a positive impact on the cultural identity of the community. The study also found that between 2008 and 2009 there was a significant decrease in the residents' concerns regarding traffic congestion; noise and pollution; crime rates; destruction of the natural environment; and unpleasantly overcrowded beaches, and bush walking paths, parks and outdoor facilities in the community. The research, however, reveals no significant differences in the residents' perceptions of conservation of natural resources; creation of employment; and the possibility of having more cultural exchange between tourists and residents due to tourism. Overall, these findings are favourable for tourism-related stakeholders in developing future tourism plans for the region in that residents' appear to be more willing to support tourism development.
\end{abstract}

Keywords: Residents’ perceptions; Tourism; Sunshine Coast; Surveys.

Título: Estudio longitudinal sobre las percepciones de los residentes de la Costa del Sol australiana sobre los impactos del turismo

Resumen: Este estudio investiga si ha habido un cambio de percepciones de los residentes de la Costa del Sol australiana sobre los impactos del turismo en el año 2009, comparándolo con el 2008. En el 2009 un mayor número de enuestados opinaron que el estilo y ritmo de vida son los principales atractivos del al Costa del Sol. Los resultados también demuestran un aumento significativo en las perepciones de los residentes sobre el impacto positivo del turismo en la identidad cultural de la comunidad. El estudio también encontró que entre el 2008 y el 2009 hubo una disminución significativa de las preocupaciones de los residentes con respecto al tráfico, el ruido y la contaminación, los índices de criminalidad, la des-trucción del medio ambiente, playas, rutas de senderimso, parques e instalaciones al aire libre. La inves-tigación, sin embargo, no revela diferencias significativas en las percepciones de los residentes sobre la conservación de los recursos naturales, la creación de empleo y la posibilidad de tener un intercambio más cultural entre turistas y residentes. En general estos resultados son favorables para las partes intere-sadas en el desarrollo de planes de futuro para turismo en la región, ya que los residentes parecen dis-puestos a apoyar el desarrollo turístico.

Palabras clave: Percepciones de los residentes; Turismo; Costa del Sol; Encuestas.

i University of the Sunshine Coast, Australia, bsharma@usc.edu.au

ii University of the Sunshine Coast, Australia. 


\section{Introduction}

The tourism literature reveals that residents' attitudes toward tourism play an important role for sustainable management of tourist destinations (Sharma and Dyer, 2009a; Sharma et al., 2008; Inbakaran and Jackson, 2006; Gursoy and Rutherford, 2004; Andriotis, 2004; Gursoy et al., 2002; Teye et al., 2002). Therefore, much attention from tourism related scholars and researchers has resulted in a large number of articles in scholarly journals which have examined various aspects of tourism including its impacts on host communities and residents' attitudes toward tourism (eg. Brida et al., 2010; Vargas-Sanchez et al., 2009; Sharma and Dyer, 2009b; Wang and Pfister, 2008; Solberg and Preuss, 2007; Inbakaran and Jackson, 2006; Teye et al., 2002; Jones et al., 2000; Fredline and Faulkner, 2000; Carmichael et al., 1996; Caneday and Zeiger, 1991).

Involvement of residents in community decision making about tourism becomes helpful in influencing and shaping the way they perceive the impacts of tourism (Bonimy, 2008). Residents comprise the general members of the public, including business owners, service providers, and workers / employees who service tourists' needs and wants. It is necessary to assess the residents' perceptions of impacts from tourism on a periodic basis as the tourismrelated activities can impact the residents' quality of life (Cecil et al., 2010). This also helps to keep the residents motivated to act as 'willing partners' in the tourism development process (Allen et al., 1988) and in identifying the impacts of tourism that could otherwise be overlooked (Mok et al., 1991). In promoting tourism, it is also important that visitors receive a high quality experience or a high level of satisfaction from their holiday along with other tourism experiences which are associated with visitors' perceptions of site-specific environmental conditions and standards. These include number of parking bays, signs, levels of littering, adequacy of human waste disposal, presence of wildlife, levels of noise, and access to beach, ocean and residents and other tourist facilities (Moore and Polley, 2007). Traffic congestion can become detrimental to both tourists and residents and negatively influence the host community's attitude towards tourism (Cros, 2008).

The findings of residents' surveys and visitors' surveys provide useful inputs to the relevant institutions in crafting or improving tourism related policies and strategies such as organising business/fun events (e.g. Australian PGA championship; Triathlons at Mooloolaba and Noosa; Woodford folk festival; Kenilworth cheese, wine and food festival; Gympie's gold rush festival; Noosa winter festival; Sunshine Coast home show and caravan and camping expo), accommodation planning, developing new tourist destinations/attractions (e.g. Premier Golf adventures; Australia zoo; Noosa national park; Suncoast barra fishing park; Kondalilla falls national park; Maleny dairies; Rainbow beach houseboats), building and improving transportation networks, and planning and scheduling air traffic/ flights. Such developments can also change residents' attitudes to tourism thus determining their level of support for tourism activities over time. However, there is a limited number of studies available which have used a longitudinal approach in assessing residents' attitudes toward tourism or visitors' perceptions of site-specific conditions and standards (Sharma and Dyer, 2010; Huh and Vogt, 2008); hence this study.

\section{Literature review}

There is an increasing interest among tourism stakeholders (e.g researchers, planners, developers) in the possible contribution of tourism to the social and economic development of a region/country ( $\mathrm{Al}-$ balate and Bel, 2010). Yet, tourism development is also challenged on the grounds of possible cultural, and/or environmental degradation (Wayakone et al., 1998). It has also been observed that cities which lead the world rankings for tourist arrivals emphasise the importance of improving the public transport network as this is crucial for improving visitors' and residents' mobility whilst preventing further traffic congestion; local/city governments are actively involved to this end in order to maintain/grow tourists inflow in cities (Albalate and Bel, 2010). A study of Arnberger and Brandenburg (2007) discussed the possible link between on-site (area) experience and crowding perceptions of visitors based on a study of a National park in Austria. This is particularly important as congestion at tourist attractions can have a negative effect on tourists' preferences for particular destinations (Brau, 2008). This warrants consideration of, and attention to, crowd management (Heung et al., 2009). Tourist destinations can become overcrowded due to inadequate management of traffic, therefore, due attention should be accorded to anticipating and managing tourism related traffic (Dickinson and Dickinson, 2006). 
Residents' beliefs and perceptions of tourism impacts influence whether or not they enjoy living in the tourist destination area. Positive perceptions of residents on social, economic and environmental impacts would lead to an increased level of willingness to support tourism and vice-versa (Inbakaran and Jackson, 2006). It is therefore, important that tourism planners develop an understanding of how the community perceives tourism to determine what they need to do to gain local support for strategic tourism related initiatives (Harrill, 2004). One way to gain local support for tourism is to involve people in the community decision-making process (Bonimy, 2008). In a separate study, using data from Folgaria in northern Italy, Brida et al. (2010) developed a basis for initiating a public participation process whereby they identified groups of people concerned about or opposed to tourism planning and development in their communities. Using cluster analysis based on positive and negative perceptions of tourism, residents were sorted into 'environmental supporters, development supporters, protectionists, and ambivalents' (Brida et al., 2010: 600). All these groups were influenced by employment in the tourism sector. Environmental supporters partially agree with the socio-cultural benefit of the tourism and the local and regional profitability of tourism but disapprove of the associated negative environmental impact. Development supporters, on the other hand, 'agree with the positive economic, environmental and socio-cultural impacts and believe that tourism increases regional profitability' while the protectionist groups 'manifest disappointment with local, cultural and environmental impacts of tourism in the region' (Brida et al., 2010: 600). Ambivalent opinions were associated with the years of residence of the host community.

As discussed by Cecil et al. (2010), the community would enjoy a good quality of life if the local residents feel safe from crime, live in affordable and high quality housing, and have access to quality education and employment opportunities, avoiding some of the tourism impact elements. Some studies, however, have not found evidence of any relationship between levels of crime and tourism (Gibson and Bentley, 2007). Wang and Pfister (2008) argued that if the residents perceive that they receive personal benefits from tourism they are likely to lend their support to tourism. How residents perceive the costs and benefits of tourism is also linked with the people's socio-demographic make-up and experience with tourism (Yang and Chen, 2008). For example, young adults are more likely to have a favourable attitude toward tourism's economic impacts than others (Huh and Vogt, 2008). Residents' attitude toward tourism is also affected by their highest education level and employment in the tourism industry (Andriotis and Vaughan, 2003).

In the Australian context, there is some notable research available which has focused on visitors' and host community reactions to tourism development (Moyle et al., 2010, Sharma et al., 2008, Moore and Polley, 2007, Fredline and Faulkner, 2000, Tideswell and Faulkner, 1999, and Tomljenovic and Faulkner, 2000). There is also some interest in the development of olive tourism (Alonso and Northcote, 2010) and wine tourism (Beames, 2003) in Australia. Other areas of research include unethical marketing practices in tourism (March, 2008), and 'blogosphere' as a market research tool for tourism destinations (Carson, 2008) among others. Most of these studies are based on case studies. Investigation of the relationship between residents' attitudes toward tourism and associated impacts, and demographic characteristics has led to mixed results (Sharma and Dyer, 2009b; Teye et al., 2002; Chen, 2000; Jones et al., 2000; Haralambopoulos and Pizam, 1996, Ritchie, 1988). There is, however, limited research that deals with the Sunshine Coast, a very popular tourist destination of Australia.

This study, therefore, focuses on the investigation of residents' perceptions of different aspects of living on the Coast and examination of differences in their attitudes towards tourism impacts between the years 2008 and 2009.

\section{Research objectives}

As discussed earlier, this study has the following objectives:

- To investigate whether there has been a change in the perceptions of residents on various aspects of living on the Sunshine Coast over a period of approximately 12 months.

- To examine whether the perceptions of residents pertaining to tourism impact items on the Sunshine, Coast has significantly changed between 2008 and 2009 .

\section{Method}

A survey approach was used for collecting data both in 2008 and 2009. The survey was divided into the following six segments: lifestyle; priority 
issues; environment / tourism impacts; economy and money; perception of residents on the effect of Council amalgamation and demography; and open-ended questions on critical issues about living on the Sunshine Coast and critical issues that face the tourism industry on the Sunshine Coast. Originally there were 28 items in the questionnaire pertaining to tourism impacts. These were based on the items developed by Gursoy and $\mathrm{Ru}^{-}$ therford (2004), and were also used by Dyer et al., (2007). They relate to positive or negative aspects of social, economic, and cultural dimensions; rating respondents' level of agreement on a 5-point scale ( $1=$ strongly disagree to $5=$ strongly agree). Of the 28 tourism impact items only $10 \mathrm{key}$ tourism impact items were selected for the 2008 survey and 15 items for the 2009 survey. Their relevance and importance were decided based on consultation with the survey sponsors, the Sunshine Coast Daily and Channel 7 (local television). Thus, the perceptions of Sunshine Coast residents regarding tourism development and its impacts focused on traffic congestion; employment; noise and pollution; the natural environment; overcrowding at leisure facilities and locations; crime rates; cultural exchange between tourists and residents; incentives for the conservation of natural resources; impact on the cultural identity of the community; and parks and recreational areas for residents. The survey was administered by the Sunshine Coast Daily (SCD). The survey was included in the daily circulation of the Sunshine Coast Daily to its regular customers, and also it was posted online in the 2008 survey. However, in 2009, the survey was carried out using entirely the online approach. The hard copy of the survey was not included in the daily circulation of the Sunshine Coast Daily. Consequently, the number of responses received was low in the 2009 sur- $^{-}$ vey. Altogether 1589 and 590 people participated in the survey in 2008 and 2009 respectively.

Various statistical techniques such as descriptive statistics (mean, standard deviation and frequency analysis), and a 't' test were used to interro' gate the data. To check for a possible response bias in the samples, mean scores for some of the items were compared for early respondents and late respondents using a 't' test. No significant difference was noted between these scores. This suggested that response bias was unlikely in the sample. The data were also checked for normality and the presence of outliers. For testing the data validity, correlation analysis of similar items in the question- naire was carried out.

\section{Results}

\section{Respondents'profile}

Although there were 1589 responses in the 2008 survey, not all of them had completed all questions. The number of responses in 2009 was 585 but as in the case of 2008, all respondents did not complete all questions in the survey. In both surveys, nearly $99 \%$ of the respondents were Sunshine Coast residents and $0.9 \%$ were visitors. In terms of age, in both surveys over $55 \%$ of respondents were 55 years or more followed by $45-54$ years. Nearly $56 \%$ of respondents were female in the 2008 survey and $60 \%$ in the 2009 survey. In both surveys over $35 \%$ of respondents had an annual household income of more than $\$ 60,000$. In terms of main occupation, $34.2 \%$ were in the 'other' category followed by 'professional' (23.7\%), home duties (12.4\%), small business owner (9.8\%), administration $(9.6 \%)$, trade $(4.5 \%)$, and retired $(3.1 \%)$, in the 2008 survey. The 'other' category included aged care worker, aged pensioner, artist tutor, carer, disability pensioner, health worker, investor, personal carer (nurse), and self-employed.

In the 2009 survey, $26.6 \%$ were in the 'other' category followed by professional category with $23.5 \%$. Further, in the 2008 survey $39 \%$ of respondents had a University level of education, followed by secondary education (33.1\%), Tertiary and further education (TAFE) (19.6\%), and an apprenticeship (5.9\%). In the 2009 survey, 36.1\% of respondents had university qualification followed by secondary education (35.4\%), and TAFE (21\%). In terms of residency in 2008, the majority of respondents in both surveys were from Maroochy area (nearly 60\%), followed by Caloundra and Noosa whereas in 2009 respondents tended to live in the coastal area. In both surveys over $40 \%$ of them had lived in the Sunshine Coast region for over 15 years. Table 1 shows the comparative profile of respondents in 2008 and 2009.

Responses to research objective 1: To investigate whether there has been a change in the perceptions of residents on various aspects of living on the Sunshine Coast.

In response to this objective, information was collected pertaining to various issues such as the residents' belief about the Coast in terms of living, their awareness of predicted population increase, their feelings about the predicted population growth, what they enjoy most about living on the 


\begin{tabular}{|c|c|c|}
\hline Particular & 2008 Survey & 2009 Survey \\
\hline Gender & $n=1564$ & $n=582$ \\
\hline Male & $690(44.1 \%)$ & $231(39.7 \%)$ \\
\hline Female & $874(55.9 \%)$ & $351(60.3 \%)$ \\
\hline Age & $n=1584$ & $n=589$ \\
\hline Under 25 yrs & $45(2.8 \%)$ & $11(1.9 \%)$ \\
\hline $25-34$ yrs & $97(6.1 \%)$ & 27 (4.6\%) \\
\hline $35-44$ yrs & $227(14.3 \%)$ & $61(10.4 \%)$ \\
\hline $45-54$ yrs & $341(21.5 \%)$ & $160(27.2 \%)$ \\
\hline 55 or more yrs & $874(55.2 \%)$ & $330(56.0 \%)$ \\
\hline Annual household income & $n=1542$ & $n=566$ \\
\hline Less than $\$ 20,000$ & $202(13.1 \%)$ & 67 (11.8\%) \\
\hline$\$ 20,000$ to $<\$ 40,000$ & $383(24.8 \%)$ & $134(23.7 \%)$ \\
\hline$\$ 40,000$ to $<\$ 60,000$ & $415(26.9 \%)$ & $144(25.4 \%)$ \\
\hline More than $\$ 60,000$ & $542(35.1 \%)$ & $221(39.1 \%)$ \\
\hline Occupation & $n=1564$ & $n=519$ \\
\hline Professional & $376(24.0 \%)$ & $122(23.5 \%)$ \\
\hline Trade & 71 (4.5\%) & 43 (8.3\%) \\
\hline Administrative & $152(9.7 \%)$ & $59(11.4 \%)$ \\
\hline Labourer & $22(1.4 \%)$ & $8(1.5 \%)$ \\
\hline Small Business Owner & $155(9.9 \%)$ & $58(11.2 \%)$ \\
\hline Home Duties & $197(12.6 \%)$ & $91(17.5 \%)$ \\
\hline Other & $591(37.8 \%)$ & $138(26.6 \%)$ \\
\hline Education & $n=1566$ & $n=587$ \\
\hline University & $611(39.0 \%)$ & $212(36.1 \%)$ \\
\hline TAFE & 307 (19.6\%) & $123(21 \%)$ \\
\hline Apprenticeship & 93 (5.9\%) & 35 (6\%) \\
\hline Secondary & $519(33.1 \%)$ & $208(35.4 \%)$ \\
\hline Primary & $36(2.3 \%)$ & $9(1.5 \%)$ \\
\hline Location of residence & $n=1564$ & $n=590$ \\
\hline Rural area & $314(20.1 \%)$ & $\begin{array}{c}\text { Coastal: } 373 \\
(63.2 \%)\end{array}$ \\
\hline Urban area & $360(23.0 \%)$ & $\begin{array}{c}\text { Non-coastal: } 207 \\
(35.1 \%)\end{array}$ \\
\hline Suburban area & $890(56.9 \%)$ & $\begin{array}{l}\text { Missing: } 10 \\
(1.7 \%)\end{array}$ \\
\hline Time lived on the Coast & $n=1572$ & $n=585$ \\
\hline All my life & 74 (4.7\%) & $36(6.2 \%)$ \\
\hline $1-3$ years & $202(12.9 \%)$ & $64(10.9 \%)$ \\
\hline 3-7 years & $277(17.6 \%)$ & $93(15.9 \%)$ \\
\hline $7-15$ years & $377(24.0 \%)$ & $151(25.8 \%)$ \\
\hline More than 15 years & $642(40.8 \%)$ & $241(41.2 \%)$ \\
\hline Residence: Previous Council & $n=1566$ & $n=575$ \\
\hline Noosa & $184(11.7 \%)$ & $52(9 \%)$ \\
\hline Maroochy & $942(60.1 \%)$ & 342 (59.5\%) \\
\hline Caloundra & $440(28.2 \%)$ & $181(31.5 \%)$ \\
\hline Residency status of respondents & $n=1582$ & $n=587$ \\
\hline Sunshine Coast resident & $99.0 \%$ & $98.6 \%$ \\
\hline Visitor & $0.9 \%$ & $1.0 \%$ \\
\hline
\end{tabular}

Table 1. Respondents’ Profile 
Coast, whether Queensland should introduce daylight saving, and the most pressing employment based issues on the Coast (see Table 2).

Nearly $53 \%$ of the respondents indicated that they did not believe that the Coast was a better place to live now and 23\% were unsure. There has been a dramatic increase in the proportion of people who thought 'lifestyle and general pace of life' was what they enjoyed most about living on the Coast (an increase from $32.3 \%$ in 2008 to $56.4 \%$ in 2009). There has been a drop, from $40.1 \%$ in 2008 to $32.4 \%$ in 2009 , in the proportion of respondents who enjoyed scenic beauty, beaches and hinterland about living on the Coast. There are four eastern states in Australia: Queensland, New South Wales, Victoria and Tasmania. There is no daylight saving in Queensland as is the case in the other 3 eastern states. In response to whether Queensland should introduce daylight saving, in both surveys, over 50\% of respondents supported daylight saving. However, there has been some drop in the proportion for support in 2009 (with 52.7\%) as compared to 2008 survey (with 57.8\%). Regarding the most pressing issue of employment on the Coast, nearly $45 \%$ of respondents in the 2008 survey, indicated a lack of senior management positions on the Coast, while in 2009 nearly 43\% indicated that the key issue was the lack of employment options/job opportunities on the Coast.

Responses to research objective 2: To examine whether Sunshine Coast residents' perceptions of tourism impact items have significantly changed between 2008 and 2009.

The results showed few significant differences in the mean scores for the items considered in this study. The notable significant differences in the residents' perceptions are summarised below (see table 3 for details).

1. There was a significant increase in the level of agreement for the item "Tourism development is likely to create a positive impact on the cultural identity of the community" in 2009 over 2008. This is a favourable outcome.

2. Another favourable response in 2009 compared

\begin{tabular}{lcc}
\hline Particular & 2008 Survey & 2009 Survey \\
\hline Awareness of predicted population increase on the Coast & $\mathrm{n}=1580$ & $\mathrm{n}=585$ \\
Yes & $61.1 \%$ & $84.1 \%$ \\
No & 38.9 & $15.9 \%$ \\
Feelings about the predicted population growth & $\mathrm{n}=1589$ & $\mathrm{n}=589$ \\
Least concerned & $3.9 \%$ & $2.9 \%$ \\
Less concerned & $3.8 \%$ & $3.6 \%$ \\
Neutral & $12.8 \%$ & $14.1 \%$ \\
Somewhat concerned & $26.1 \%$ & $29.2 \%$ \\
Most concerned & $51.9 \%$ & $48.2 \%$ \\
Belief about the Coast being a better place to live & & $\mathrm{n}=582$ \\
Yes & & $23.7 \%$ \\
No & & $53.1 \%$ \\
Unsure & & $23.2 \%$ \\
Enjoy most about living on the Coast & $\mathrm{n}=1463$ & $\mathrm{n}=510$ \\
Scenic beauty - beaches, hinterland etc. & $40.1 \%$ & $32.4 \%$ \\
Lifestyle and general pace of life & $32.3 \%$ & $56.5 \%$ \\
Job prospects and availability & $10.1 \%$ & $1.0 \%$ \\
Supporting infrastructure - roads, public transport etc. & $4.0 \%$ & $0.2 \%$ \\
Access to healthcare and education & $1.0 \%$ & $1.2 \%$ \\
Proximity to family and friends & $1.4 \%$ & $5.7 \%$ \\
Other & $11.1 \%$ & $3.0 \%$ \\
Should QLD introduce daylight saving & $\mathrm{n}=1558$ & $\mathrm{n}=569$ \\
Yes & $57.8 \%$ & $52.7 \%$ \\
No & $42.2 \%$ & $47.3 \%$ \\
Most pressing employment based issues on the Coast & $\mathrm{n}=1405$ & $\mathrm{n}=527$ \\
Lack of employment options/job opportunities & $18.7 \%$ & $42.7 \%$ \\
Significantly lower salary levels than metro cities & $17.6 \%$ & $15.4 \%$ \\
Lack of job diversity on the coast & $18.9 \%$ & $21.1 \%$ \\
Lack of senior management opportunities & $44.8 \%$ & $3.2 \%$ \\
Lack of part time/casual roles & - & $12 \%$ \\
Other & - & \\
\hline
\end{tabular}

Table 2. : Respondents' perceptions of population size, living on the Coast, employment based issues on the Coast 


\begin{tabular}{|c|c|c|c|c|c|c|c|}
\hline \multirow[b]{3}{*}{ Tourism impact items } & \multirow{2}{*}{\multicolumn{3}{|c|}{ 2009 Survey }} & \multirow{2}{*}{\multicolumn{3}{|c|}{ 2008 Survey }} & \multirow[b]{3}{*}{ 't' value } \\
\hline & & & & & & & \\
\hline & $\begin{array}{l}\text { Mean }^{1} \\
\text { (SD) }[\mathrm{n}]\end{array}$ & $\begin{array}{l}\text { \% who } \\
\text { agree } \\
\text { and } \\
\text { strongly } \\
\text { agree }^{2}\end{array}$ & $\begin{array}{c}\% \text { who } \\
\text { disagree } \\
\text { and } \\
\text { strongly } \\
\text { disagree }^{3}\end{array}$ & $\begin{array}{l}\text { Mean } \\
\text { (SD) } \\
\text { [n] }\end{array}$ & $\begin{array}{l}\text { \% who } \\
\text { agree and } \\
\text { strongly } \\
\text { agree }\end{array}$ & $\begin{array}{c}\text { \% who } \\
\text { disagree } \\
\text { and } \\
\text { strongly } \\
\text { disagree }\end{array}$ & \\
\hline $\begin{array}{l}\text { Tourism development is likely to provide an } \\
\text { incentive for the conservation of natural } \\
\text { resources. }\end{array}$ & $\begin{array}{c}3.36 \\
(1.36) \\
{[579]}\end{array}$ & 54.7 & 29.7 & $\begin{array}{c}3.31 \\
(1.40) \\
{[1558]}\end{array}$ & 53.8 & 32.7 & -0.79 \\
\hline $\begin{array}{l}\text { Tourism is a key industry that provides } \\
\text { essential jobs in the region. }\end{array}$ & $\begin{array}{l}4.5 \\
(0.97) \\
{[585]}\end{array}$ & 89.2 & 6.2 & $\begin{array}{c}4.43 \\
(0.99) \\
{[1572]}\end{array}$ & 88.3 & 6.9 & -1.54 \\
\hline $\begin{array}{l}\text { Tourism is likely to result in more cultural } \\
\text { exchange between tourists and residents. }\end{array}$ & $\begin{array}{c}3.58 \\
(1.20) \\
{[587]}\end{array}$ & 57.2 & 19.3 & $\begin{array}{c}3.51 \\
(1.21) \\
{[1563]}\end{array}$ & 55.8 & 21.2 & -1.15 \\
\hline $\begin{array}{l}\text { Tourism development is likely to create } \\
\text { positive impact on the cultural identity of } \\
\text { your community. }\end{array}$ & $\begin{array}{l}3.40 \\
(1.28) \\
{[585]}\end{array}$ & 50.4 & 24.8 & $\begin{array}{l}3.25 \\
(1.27) \\
{[1561]}\end{array}$ & 45.2 & 28.3 & $-2.47^{*}$ \\
\hline $\begin{array}{l}\text { Tourism development is likely to provide } \\
\text { more parks and other recreational areas for } \\
\text { local residents. }\end{array}$ & $\begin{array}{l}3.21 \\
(1.35) \\
{[582]}\end{array}$ & 47.3 & 35.1 & $\begin{array}{c}3.09 \\
(1.36) \\
{[1567]}\end{array}$ & 44.4 & 37.6 & $-1.8 \dagger$ \\
\hline $\begin{array}{l}\text { Tourism is likely to result in traffic } \\
\text { congestion. }\end{array}$ & $\begin{array}{l}4.32 \\
(1.06) \\
{[587]}\end{array}$ & 83.3 & 8.5 & $\begin{array}{l}4.46 \\
(1.01) \\
{[1570]}\end{array}$ & 86.3 & 6.3 & $2.86^{* *}$ \\
\hline $\begin{array}{l}\text { Tourism is likely to result in noise and } \\
\text { pollution. }\end{array}$ & $\begin{array}{l}3.88 \\
(1.19) \\
{[581]}\end{array}$ & 67.1 & 14.5 & $\begin{array}{l}4.07 \\
(1.16) \\
{[1570]}\end{array}$ & 73.9 & 11.9 & $3.42^{* *}$ \\
\hline Tourism is likely to increase the crime rate. & $\begin{array}{c}3.42 \\
(1.30) \\
{[582]}\end{array}$ & 50 & 28.2 & $\begin{array}{c}3.56 \\
(1.27) \\
{[1569]}\end{array}$ & 54.2 & 21.8 & $2.30^{*}$ \\
\hline $\begin{array}{l}\text { Construction of hotels and other tourist } \\
\text { facilities are likely to destroy the natural } \\
\text { environment. }\end{array}$ & $\begin{array}{l}3.66 \\
(1.27) \\
{[585]}\end{array}$ & 60.7 & 21.5 & $\begin{array}{l}3.84 \\
(1.32) \\
{[1571]}\end{array}$ & 66.9 & 19.4 & $2.91^{* *}$ \\
\hline $\begin{array}{l}\text { Tourism is likely to result in unpleasantly } \\
\text { overcrowded beaches, bush walking paths, } \\
\text { parks and other outdoor places in your } \\
\text { community. }\end{array}$ & $\begin{array}{l}3.49 \\
(1.30) \\
{[576]}\end{array}$ & 55.6 & 26.2 & $\begin{array}{c}3.73 \\
(1.28) \\
{[1569]}\end{array}$ & 63 & 20.1 & $3.80^{* * *}$ \\
\hline
\end{tabular}

Note: * stands for $p<0.05, * \star$ for $p<0.01$ and $* \star \star$ for $p<0.001$ and $\dagger$ for $p<0.10$.

1 Mean of five point scale: $1=$ strongly disagree, $5=$ strongly agree. SD $=$ Standard Deviation and $\mathrm{n}=$ sample size

2 Combination of 4 and 5 on a five-point scale

3 Combination of 1 and 2 on a five-point scale

Table 3. Test of Difference in Residents’ Responses on Tourism Impact Items

to 2008 related to the observation that "Tourism is likely to provide more parks and other recreational areas for local residents".

3. There was a significant reduction in the level of agreement that "Tourism is likely to result in traffic congestion" and "Tourism is likely to result in noise and pollution". This is perhaps due to the construction of new roads and upgrading of existing roads in recent times.

4. There has also been a decrease in the residents' level of agreement in 2009 compared to 2008 in the following items: 1) tourism is likely to increase the crime rate, 2) construction of hotels and other tourist facilities are likely to destroy the natural environment, and 3) tourism is likely to result in unpleasantly overcrowded beaches, bush walking paths, parks and other outdoor places in the community. These changes in residents' perceptions are favourable in terms of gaining support for further development of tourism activities on the Coast.

5. In 2009 data were recorded for five extra tourist impact items such as "tourism is likely to attract more investment to the community", "high spending tourists are likely to affect negatively our way of living", "the cost of developing facilities is too much", "tourism is likely to provide more business for local people and small 
business", and "local residents are likely to suffer from living in tourism destination". Comparative analyses cannot be carried out for these at this time.

6. No significant difference in the residents' perceptions was found between 2008 and 2009 for the following tourism impact items: 1) tourism development is likely to provide an incentive for the conservation of natural resources, 2) tourism is a key industry that provides essential jobs in the region, and 3) tourism is likely to result in more cultural exchange between tourists and residents.

\section{Discussion}

This study identified changes as perceived by the Sunshine Coast residents on various aspects of living on the Coast and also investigated the difference in residents' perceptions of tourism impacts between 2008 and 2009. In spite of using similar approaches for collecting the information in 2008 and 2009 surveys, some demographic differences were noted between these samples. This difference is perhaps explained by the ongoing growth of population on the coast affecting the collective character of the community. It could also perhaps be because of difference in the set of respondents in completing the survey. This should be taken into account when making decisions based on these findings.

In response to the first research objective, it is suggested that the proportion of people who perceive the Coast to be a better place to live is fewer than half of the respondents who perceive the Coast not to be a better place to live now. These findings warrant further investigation to determine expectations in order to develop the Coast such that it becomes more attractive not only for the tourists but also for the local residents. In the 2009 survey, a slight majority of respondents $(56.5 \%)$ indicated lifestyle and general pace of life as the key aspect they enjoyed most about living on the Coast. This is a significant increase from the 2008 survey (32.3\%). The scenic beauty such as beaches and the hinterland were considered to be the key aspects that the residents enjoyed about living on the Coast in 2008 (40.1\%), but this decreased to $32.4 \%$ in 2009 . The day light saving has been another topic of debate in Queensland. The results indicate that the support for the introduction of daylight saving has gone down to $52.7 \%$ in 2009 from $57.8 \%$ in 2008 . The survey had also collected information on residents' awareness about predicted population increase on the Coast. The results suggest that the level of awareness has significantly increased in 2009 to $84.1 \%$ from $61.1 \%$ in 2008. However, in terms of respondents' feelings about the predicted population growth, the level of concern has more or less remained the same. In terms of the most pressing employment based issues on the Coast, nearly $45 \%$ indicated that a lack of senior management opportunities was the major issue in 2008 whereas the 2009 survey indicated that a lack of employment options or job opportunities was the most pressing employment based issue on the Coast.

In response to the second research objective, a ' $\mathrm{t}$ ' test was carried out for the 10 common tourism impact items considered in this study. The results indicated significant differences in perceptions of residents in seven items with different levels of significance as indicated in table 3 . For example, there was a significant difference in 1 item at a p-value of less than $0.001,3$ items at a p-value of less than $0.01,2$ items at a p-value of 0.05 level and 1 item at a p-value of 0.10 . The residents' perceptions of tourism impacts are encouraging for the tourism planners and developers for seeking support for tourism as residents appeared more favourable towards tourism in 2009 compared to those in 2008. For example, there is a decrease in their level of agreement in possible traffic congestion, noise and pollution, and increase in crime rates in 2009 from that of 2008. However, residents' perceptions of tourism's role in providing essential jobs, proving incentive for the conservation of natural resources, and the possibility of having more cultural exchange between tourists and residents have remained unchanged. There is a need to carry out another survey to monitor residents' attitudes in the five new items added in 2009. Generally, it is necessary to continue to receive support from local residents for tourism to inform and assist the relevant tourism institutions, local government authorities, planners and developers decision making, thus it is important to monitor such information on an on-going basis to address the concerns of local residents when making strategic interventions. Also, this research highlights the dynamism of residents' perceptions which are influenced by changing circumstances from year to year at a local level. Regular monitoring is important to elucidate these nuances.

The study has the following limitations: 1) difference in the sample size between the years (2008 and 2009) and 2) the difference in the data collection 
techniques used in 2008 and 2009. As discussed earlier in the 'Methods' section, in the 2009 survey the data collection was based on the online approach whereas in the 2008 survey, along with online posting, a hard copy of the survey was included in the daily circulation of the Sunshine Coast Daily. This could have resulted in sample bias (web-user vs. the people having access to the newspaper through various other formats/modes).

\section{References}

Albalate, D. and Bel, G.

2010. "Tourism and urban public transport: Holding demand pressure under supply constraints." Tourism Management, 31(3): 425-433.

Allen, L. R., Long, P. T., Perdue, R. R. and Kieselbach, $\mathrm{S}$.

1988. "The impact of tourism development on residents' perceptions of community life." Journal of Travel Research, 27(1): 16-21.

Alonso, A.D. And Northcote, J.

2010. The development of olive tourism in Western Australia: a case study of an emerging tourism industry." International Journal of Tourism Research, 12(6): 696-708.

Andriotis, $\mathrm{K}$.

2004. "The perceived impact of tourism development by Cretan residents." Tourism and Hospitality Planning and Development, 1(2): 123-144.

Andriotis, K. and Vaughan, R.D.

2003. "Urban residents' attitudes toward tourism development: The case of Crete." Journal of Travel Research, 42(2): 172.

Arnberger, A. and Brandenburg, C.

2007. "Past on-site experience, crowding perceptions, and use displacement of visitor groups to a peri-urban national park." Environmental Management, 40: 34

Beames, G.

2003. "The rock, the reef and the grape: the challenges of developing wine tourism in regional Australia." Journal of Vacation Marketing, 9(3): 205-212.

Bonimy, M.M.

2008. "Residents' attitudes and perceptions towards the impact of tourism on the environment in $\mathrm{Pi}^{-}$ geon Forge, Tennessee." PhD Thesis, Tennessee State University.

Brau, R.

2008. "Demand-driven sustainable tourism? A choice modelling analysis." Tourism Economics, 14(4): 691-708.
Brida, J.G., Osti, L. And Barquet, A.

2010. "Segmenting resident perceptions towards tourism - a cluster analysis with a multinominal logit model of a mountain community." International Journal of Tourism Research, 12: 591-602.

Caneday, L. and Zeiger, J.

1991. "The social, economic, and environmental costs of tourism to a gaming community as perceived its residents." Journal of Travel Research, 30(2): 45-49.

Carmichael, B.A., Peppard, D.M. and Boudreau, F.A.

1996. "Megaresort on my doorstep: Local resident attitudes toward Foxwoods Casino and casino gambling on nearby Indian reservation land." Journal of Travel Research, 34(3): 9-16.

Carson, D.

2008. 'The 'blogosphere' as a market research tool for tourism destinations: a case study of Australia's Northern Territory." Journal of Vacation Marketing, 14(2): 111-119.

Cecil, A.K., Fu, Y.Y., Wang, S. and Avgoustis, S.

2010. "Cultural tourism and quality of life: Results of a longitudinal study." European Journal of Tourism Research, 3(1): 54-66.

Chen, J.S.

2000. "An investigation of urban tourism residents' loyalty of tourism." Journal of Travel and Tourism Research, 24(1): 5-19.

Cros, H. d.

2008. "Too much of a good thing? Visitor Congestion management issues for popular world heritage tourist attractions." Journal of Heritage Tourism, 2(3): $225-238$.

Dickinson, J. E. and Dickinson, J.A.

2006. "Local transport and social representations: Challenging the assumptions for sustainable tourism." Journal of Sustainable Tourism, 14(2): $192-208$.

Dyer, P., Gursoy, D., Sharma, B. and Carter, J.

2007. "Structural modelling of resident perceptions of tourism and associated development on the Sunshine Coast, Australia." Tourism Management, 28: 409-422.

Fredline, E. and Faulkner, B.

2000. "Host community reactions: A cluster analysis." Annals of Tourism Research, 27(3): 763-784.

Gibson, P. and Bentley, M.

2007. "A study of impacts-cruise tourism and the South West of England." Journal of Travel and Tourism Marketing, 20(3): $63-77$.

Gursoy, D. and Rutherford, D.G.

2004. "Host attitudes toward tourism - An improved structural model." Annals of Tourism Research, 
31(3): 495-516.

Gursoy, D., Jurowski, C. and Uysal, M.

2002. "Resident attitudes - A structural modelling approach." Annals of Tourism Research, 29(1): 79-105.

Haralambopoulos, N. and Pizam, A.

1996. "Perceived impacts of tourism: The case of Samos." Annals of Tourism Research, 23(3): 503526.

Harrill, R.

2004. 'Residents' attitudes toward tourism development: A literature review with implications for tourism planning." Journal of Planning Literature, 18(3): 251.

Heung, V. C. S., Tsang, N., et al.,

2009. "Queuing behavior in theme parks: A comparison between Chinese and Western tourists." Journal of China Tourism Research, 5(1): $41-51$

Huh, C. and Vogt, C.A.

2008. "Changes in residents' attitudes toward tourism over time: A cohort analytical approach." Journal of Travel Research, 46(4): 446.

Inbakaran, R. and Jackson, M.

2006. "Resident attitudes inside Victoria's tourism product regions: A cluster analysis." Journal of Hospitality and Tourism Management, 13(1): 59-74.

Jones, D. L., Jurowski, C. and Uysal, M.

2000. "Host community residents' attitudes: A comparison of environmental viewpoints." Tourism and Hospitality Research, 2(2): 129-155.

March, R.

2008. "Towards a conceptualisation of unethical marketing practices in tourism: a case study of Australia's inbound chinese travel market." Journal of Travel and Tourism Marketing, 24(4): 255.

Mok, C., Slater, B. and Cheung, V.

1991. "Residents' attitudes towards tourism in Hong Kong." International Journal of Hospitality Management, 10(3): 289-293.

Moore, S.A. and Polley, A.

2007. "Defining indicators and standards for tourism impacts in protected areas: Cape Range national Park, Australia." Environmental Management, 39: 291-300.

Moyle, B., Croy, W.G. and Weiler, B.

2010. "Community perceptions of tourism: Bruny and Magnetic Islands, Australia." Asia Pacific Journal of Tourism Research, 15(3): 353 - 366.

Ritchie, J. R. B.

1988. "Consensus policy formulation in tourism: Measuring resident views via survey research." Tourism Management, 9(3): 199-212.

Sharma, B. and Dyer, P.

2009a. "An empirical investigation of the relationship between residents' involvement in tour- ism and their perceptions of tourism impacts." Benchmarking: An International Journal, 16(3).

Sharma, B. and Dyer, P.

2009b. "An investigation of differences in residents' perceptions on the Sunshine Coast: Tourism impacts and demographic variables." Tourism Geographies, 11(2): 187-213.

Sharma, B. and Dyer, P.

2010. "Sunshine Coast residents' perceptions of tourism impacts: A longitudinal study." In $\mathrm{M} \mathrm{Ke}^{-}$ falaki and Daniel Tixier (Eds.), Challenges and Prospects in Tourism Research (pp. 175 - 188). Greece: Atiner Publication.

Sharma, B., Dyer, P., Carter, J. and Gursoy, D.

2008. "Exploring residents' perceptions of the social impacts of tourism on the Sunshine Coast, Australia." International Journal of Hospitality and Tourism Administration, 9(3): 288-311.

Solberg, H.A. and Preuss, H.

2007. "Major sport events and long-term tourism impacts." Journal of Sport Management, 21: 213234.

Teye, V., Sonmez, S.F. and Sirakaya, E.

2002. "Residents' attitudes toward tourism development." Annals of Tourism Research, 29(3): 668688.

Tideswell, C. and Faulkner, B.

1999. "Multidestination travel patterns of international visitors to Queensland." Journal of Travel Research, 37: 364-374.

Tomljenovic, R. and Faulkner, B.

2000. "Tourism and older residents in a sunbelt resort." Annals of Tourism Research, 27(1): 93-114.

Vargas-Sanchez, A., Plaza-Mejia, M.A. and PorrasBueno, N.

2009. "Understanding residents' attitudes toward the development of industrial tourism in a former mining community." Journal of Travel Research, 47(3): 373 .

Wang, Y. and Pfister, R.E.

2008. "Residents' attitudes toward tourism and perceived personal benefits in a rural community." Journal of Travel Research, 47(1): 84.

Wayakone, S., Daud, M., Bardaie, M.Z., Shuib, A. and Mohd, A.

1998. "Residents' attitude towards future impacts of tourism development in Langkawi." Borneo Review, 9(2): 123-134.

Yang, J.Y.C. and Chen, Y.M.

2008. "Nature-based tourism impacts in I-Lan, Taiwan: business managers' perceptions." International Journal of Culture, Tourism and Hospitality Research, 2(3): 250-270.

$\begin{array}{ll}\text { Recibido: } & 15 / 02 / 2011 \\ \text { Reenviado: } & 30 / 09 / 2011 \\ \text { Aceptado: } & 31 / 10 / 2011\end{array}$

Sometido a evaluación por pares anónimos 